Letrônica, Porto Alegre, v. 7, n. 2, p. 713-738, jul./dez., 2014

\title{
DISPERSÃO ACÚSTICA DAS VOGAIS EM TRÊS LÍNGUAS TUPÍ
}

\author{
ACOUSTIC VOWEL DISPERSION IN THREE TUPIAN LANGUAGES
}

\author{
Fabíola Baraúna* \\ Alessandra Brito** \\ Gessiane Picanço***
}

\begin{abstract}
Resumo: Este estudo aborda duas questões em relação ao inventário de vogais das línguas Asuriní do Xingu, Wayampí e Mundurukú, todas do tronco Tupí. A primeira questão refere-se à tendência universal dos sistemas vocálicos serem iguais e simetricamente distribuídos. A segunda refere-se à importância de uma análise acústica na discussão de fatos fonológicos, principalmente quando se trata de uma descrição mais precisa das realizações fonéticas de segmentos. A pesquisa tem como foco a definição das qualidades vocálicas e sua distribuição no espaço acústico de vogais nas três línguas. O Asuriní, apesar de contar com alguns estudos anteriores de sua fonologia, permanecia ainda indefinido em relação a suas qualidades vocálicas. Um cenário semelhante era encontrado na língua Wayampí; essa língua possui um sistema vocálico simetricamente bem arranjado, mas também havia dúvidas quanto às suas vogais. A análise acústica contribuiu para esclarecer essas diferenças. O Mundurukú, por outro lado, vem contribuir como um exemplo de uma língua tipologicamente incomum, já que seu sistema vocálico não possui o esperado triângulo /i, u, a/. No entanto, a análise acústica demonstra que, foneticamente, parece haver uma compensação por parte das vogais atuais, aproximando a língua da simetria que é esperada na distribuição de vogais.

Palavras-chave: Vogais; Análise acústica; Dispersão vocálica; Línguas Tupí.
\end{abstract}

\begin{abstract}
This study addresses two issues regarding the inventory of vowels in the Tupian languages Asuriní Xingu, and Wayampí Mundurukú. The first issue refers to the universal tendency for vowel systems to be equally and symmetrically distributed. The second refers to the importance of an acoustic analysis in the discussion of phonological facts, especially when it comes to a more accurate phonetic description of segments. The research focuses on the definition of vowel qualities and their distribution in the acoustic space of vowels in the Tupian languages. Despite having some previous studies of its phonology, Asuriní do Xingu remained undefined in relation to their vowel qualities. A similar scenario is found in Wayampí, a language with a vowel system symmetrically dispersed, but still with doubts
\end{abstract}

\footnotetext{
* Mestranda do Programa de Pós-Graduação em Letras da Universidade Federal do Pará (PPGL/UFPA). Bolsista do Conselho Nacional de Desenvolvimento Científico e Tecnológico (CNPq), inserida nos projetos "Padrões dos Sons das Línguas Indígenas Brasileiras" e Reconstrução Fonológica do Proto-Mundurukú (Tupí).

** Graduada em Letras pela Universidade Federal do Pará (UFPA), inserida no projeto Reconstrução Fonológica do Proto-Mundurukú (Tupí).

*** Doutora em Linguística pela University of Britsh Columbia (2005), Professora Adjunta da Universidade Federal do Pará no Instituto de Letras e Comunicação e na Pós-Graduação em Letras da referida universidade. Atualmente, coordena o projeto Reconstrução Fonológica do Proto-Mundurukú (Tupí), financiado pelo CNPq, Processo No. 406326/2012-6.
} 
about its vowel qualities. The acoustic analysis helps to clarify these discrepancies. Mundurukú contributes to the study as an example of a language typologically uncommon since its vowel system does not have the expected triangle /i, u, a/. However, the acoustic analysis shows that, at least phonetically, the gaps seem to be compensated for by other vowels, so that the language is closer to a symmetric system.

Keywords: Vowels; Acoustic analysis; Vowel dispersion; Tupian languages.

\section{Introdução}

Cerca de $80 \%$ das 451 línguas que atualmente integram o UCLA Phonological Segment Inventory Database (UPSID ${ }_{451}$, MADDIESON \& PRECODA, 1989) ${ }^{1}$ possuem as vogais [i], [a] e [u], o chamado sistema triangular, em seus inventários. Em contraste, os sistemas que incluem as vogais [y], [œ] e [u] não chegam a 10\% das ocorrências².

\section{(1) Sistema triangular}

[i] $\quad[\mathrm{u}]$

[a]

As línguas do mundo também tendem a exibir uma distribuição simétrica em seus sistemas vocálicos (LILJENCRANTS \& LINDBLOM, 1972). Se uma língua tem uma vogal anterior de certa altura (por exemplo, $[\varepsilon]$ ), também tende a ter uma vogal posterior com altura equivalente (por exemplo, [?]).

(2) Sistema simétrico de 5 vogais

[i] [u]

$[\varepsilon] \quad[0]$

[a]

Tendências universais como as descritas acima têm chamado a atenção já há algum tempo (ex., Troubetzkoy (1969 [1939]); Crothers (1978); Maddieson (1984); Liljencrants \& Lindblom (1972), entre outros), e contam com diferentes explicações, sejam fonológicas ou fonético-acústicas. Neste último grupo encontra-se o Princípio da

\footnotetext{
${ }^{1}$ A primeira versão do UPSID é descrita em Maddieson (1984).

${ }^{2}$ Fonte: http://web.phonetik.uni-frankfurt.de/upsid segment freq.html.
} 
Dispersão Vocálica de Liljencrants \& Lindblom (1972), que diz que um sistema utilizará primeiro os pontos maximamente distantes do espaço acústico das vogais, e só depois seus pontos intermediários, dependendo do número de vogais da língua. Esse princípio prevê, por exemplo, que sistemas como o ilustrado abaixo dificilmente ocorrerão em línguas naturais.

(3) Sistema pouco provável

[i] $\quad[\mathrm{u}]$

[o]

[æ]

[a]

Neste estudo apresentaremos a distribuição acústica dos inventários fonêmicos de vogais em três línguas Tupí: Asuriní do Xingu, Wayampí e Mundurukú.

A língua Asuriní pertence à família Tupí-Guaraní e está subdividida em Asuriní do Tocantins (ou do Trocará) e Asuriní do Xingu. Sua classificação nos subgrupos que compõem a família é divergente. Rodrigues e Cabral (2002) inserem o Asuriní do Tocantins no subgrupo IV, juntamente com Tapiraré, Parakanã, Suruí, Avá-Canoeiro, Guajajára e Turiwára; já o Asuriní do Xingu é inserido no subgrupo V, juntamente com Araweté, Ararandewára-Amanajé e Anambé do Cairarí. Por outro lado, Mello (2000) classifica o Asuriní do Xingu (e do Tocantins) como pertencente ao subgrupo VI, juntamente com Suruí, Parakanã, Tembé e Tapirapé. Os Asuriní do Xingu localizam-se a alguns quilômetros da cidade de Altamira, sudeste do Pará, na Terra Indígena Koatinemo, à margem direita do Rio Xingu.

A língua Wayampí também pertence à família Tupí-Guaraní. Rodrigues e Cabral (2002) colocam-na no subgrupo VIII, juntamente com Wayampípukú, Emérillon, UrubuKa'apór, Jo'é, Anambé de Ehrenreich, Guajá, Awré e Awrá e Takunhapé. Os índios Wayampí habitam uma região entre o Brasil, estado do Amapá, e a Guiana Francesa. No Brasil eles se dividem em Wayampí do Jari e Wayampí do Amapari.

A língua Mundurukú pertence à família Mundurukú, juntamente com Kuruaya (RODRIGUES, 1986), uma língua já extinta. Sua população está quase que totalmente distribuída em dois estados brasileiros: a maioria reside no Pará (cerca de 7.000 
habitantes), e a outra parte reside no Amazonas (cerca de 3.000$)^{3}$. A língua nativa é ainda falada regularmente no Pará, mas o grupo do Amazonas já fala somente o português. Portanto, os dados utilizados neste estudo referem-se à variante Mundurukú do Pará.

\section{Metodologia}

A verificação das propriedades acústicas foi realizada com relação às vogais tônicas das três línguas e ocorreu com auxílio do programa Praat, software comumente utilizado na análise de fala, em que é possível explicitar diversos parâmetros acústicos por meio dos espectrogramas e ondas sonoras.

Ladefoged (1971) afirma que a teoria fonte-filtro permite distinguir as vogais umas da outras. 0 trato vocal pode ser concebido como um tubo que apresenta uma fonte acústica de energia; no caso das vogais, esta fonte é a perturbação originada pela vibração das cordas vocais. Assim também, o trato vocal caracteriza-se como um filtro acústico, uma vez que a qualidade auditiva da vogal poderá se modificar conforme os diferentes formatos do trato vocal. Deste modo, constata-se que as vogais apresentam ressonâncias específicas no trato vocal denominadas de formantes. Destacam-se quatro formantes: o primeiro formante (F1) corresponde ao grau de abertura da cavidade oral, o segundo formante (F2) se refere ao movimento de avanço e recuo da língua no trato, o terceiro formante (F3) reproduz o movimento dos lábios, o quarto formante (F4) relaciona-se a nasalidade (SILVA, 2012). Destes formantes, utilizaremos para nossa análise somente F1 e F2, que são suficientes para caracterizar as vogais em relação à altura e à posição anterior-posterior no trato vocal.

As gravações para a língua Asuriní do Xingu foram realizadas por Ana Sousa, com uma falante nativa em 2009. Assim também, para a língua Wayampí utilizou-se uma gravação realizada por Elissandra Barros, com um falante nativo da língua, em 2010, no Oiapoque, estado do Amapá. ${ }^{4}$ Para análise acústica da língua Asuriní do Xingu selecionou-se uma média de 15 (30) amostras por vogal, ou seja, 15 (30) repetições de

\footnotetext{
${ }^{3}$ Fonte: <http://pib.socioambiental.org/pt/povo/munduruku>. Segundo o Instituto Socioambiental, há também alguns Mundurukú residindo no Mato Grosso.

${ }^{4}$ As gravações foram feitas com gravador profissional Marantz Pmd 620, em formato WAV, com microfone do tipo headset (de cabeça) Sennheiser, também profissional; a taxa de amostragem do sinal foi $44.100 \mathrm{~Hz}$, 16 Bitz e mono.
} 
cada qualidade vocálica, totalizando 120 (180) amostras de vogais, retiradas de uma lista de aproximadamente 650 palavras. Já para a análise da língua Wayampí selecionouse uma média de 18 amostras por vogal, ou seja, 18 repetições de cada qualidade vocálica, totalizando 144 amostras de vogais, retiradas de uma lista de aproximadamente 600 palavras. Quanto ao Mundurukú, os dados provêm de três falantes nativos, totalizando aproximadamente 149 amostras, com média de 29 amostras por vogal (ver detalhes em Picanço (2005)). As palavras utilizadas para análise acústica podem ser verificadas nos anexos deste trabalho.

Em uma planilha de Excel foram organizados os valores $(\mathrm{Hz})$ do primeiro e segundo formantes, F1 e F2, respectivamente. Para retirar os valores destes formantes, centralizou-se o cursor no ponto mais estável da vogal, ou seja, no ponto em que a vogal apresenta certa regularidade com relação às suas frequências, clicando em F1 para visualizar o valor correspondente ao primeiro formante $(\mathrm{Hz})$ e F2 para visualizar o valor do segundo formante $(\mathrm{Hz})$. Por fim, foi elaborado um gráfico de dispersão acústica referente às vogais tônicas consideradas neste estudo. A partir deste gráfico foi realizada a discussão acerca das características acústicas das vogais.

\section{Asuriní do Xingu}

Há alguns estudos sobre a língua Asuriní do Xingu que trazem propostas diferentes acerca de sua fonologia segmental. A primeira é fornecida em Nicholson (1982), no trabalho intitulado "Breve Estudo da Língua Asuriní do Xingu”, que trata de aspectos mais gerais da língua. Nesse trabalho a autora faz uma comparação entre a variante do Xingu e a do Trocará, dando maior ênfase à gramática da língua do que aos seus aspectos fonológicos. A segunda aparece em Pereira (2009), "Estudo Morfossintático do Asuriní do Xingu", que apresenta breve análise sobre os fonemas da língua. Nesse estudo podem-se encontrar mais detalhes das vogais, incluindo um quadro fonético e outro fonológico de suas qualidades. Mesmo assim, os dois trabalhos apresentam propostas diferentes para o inventário fonético-fonológico dessa língua.

Nicholson (1982) propõe um sistema com seis qualidades contrastivas de vogais, como apresentado em (4); são três vogais altas, uma anterior não-arredondada /i/, uma central não-arredondada /íl e uma posterior arredondada /u/; duas na região média, 
sendo uma posterior médio-alta arredondada /o/ e uma anterior médio-baixa nãoarredondada $/ \varepsilon /$, além da vogal central não-arredondada /a/. Essa classificação difere de outra anterior (NICHOLSON, 1978) na qual cinco vogais foram propostas, /i, i, $\varepsilon, a, o /$.

(4) Inventário fonêmico de vogais Asuriní, baseado em Nicholson (1982, p. 4)

\begin{tabular}{l|c|c|c|}
\multicolumn{1}{c}{ Anterior } & Central & \multicolumn{1}{c|}{ Posterior } \\
\cline { 2 - 4 } Alta & $/ \mathrm{i} /$ & $/ \mathrm{i} /$ & $/ \mathrm{u} /$ \\
Média & $/ \varepsilon /$ & & $/ \mathrm{o} /$ \\
\cline { 2 - 4 } Baixa & & $/ \mathrm{a} /$ & \\
\cline { 2 - 4 } & &
\end{tabular}

Foneticamente, essas vogais são realizadas conforme (5) a seguir. Aqui já podemos observar a assimetria em relação à altura das vogais na região média, no que $[\varepsilon]$, uma vogal anterior médio-baixa não-arredondada, tem como correspondente posterior a vogal médio-alta arredondada [o].

(5) Inventário fonético de vogais Asuriní, baseado em Nicholson (1982, p. 4)

\begin{tabular}{l|c|c|c|}
\multicolumn{1}{c}{} & \multicolumn{1}{c}{ Anterior } & Central & \multicolumn{1}{c}{ Posterior } \\
\cline { 2 - 4 } Alta & {$[\mathrm{i}]$} & {$[\mathrm{i}]$} & {$[\mathrm{u}]$} \\
\cline { 2 - 4 } Média & & & {$[\mathrm{o}]$} \\
& {$[\varepsilon]$} & & \\
\cline { 2 - 4 } Baixa & & {$[\mathrm{a}]$} & \\
\cline { 2 - 4 } & &
\end{tabular}

Uma proposta levemente diferente para o sistema vocálico do Asuriní aparece em Pereira (2009), que propõe um inventário fonêmico contendo cinco qualidades de vogais: três vogais altas (/i/, /i / e /u/), uma anterior médio-alta /e/ e uma central baixa /a/, conforme apresentado no quadro (6). Os estudos de Nicholson e Pereira divergem principalmente em relação à vogal posterior /o/, que não é reconhecida por Pereira; na região posterior ela assume que há somente o $/ \mathrm{u} /$. 
(6) Inventário fonêmico de vogais Asuriní, baseado em Pereira (2009, p. 37)

\begin{tabular}{l|c|c|c|}
\multicolumn{1}{c}{} & \multicolumn{1}{c}{ Anterior } & Central & \multicolumn{1}{c}{ Posterior } \\
Alta & $/ \mathrm{i} /$ & $/ \mathrm{i} /$ & $/ \mathrm{u} /$ \\
\cline { 2 - 4 } Média & $/ \mathrm{e} /$ & & \\
\cline { 2 - 4 } Baixa & & $/ \mathrm{a} /$ & \\
\cline { 2 - 4 } & &
\end{tabular}

De acordo com Pereira, /i/, /ì e /a/ apresentam uma variante cada, [i], [i] e [a], respectivamente; o mesmo parece ser o caso de /u/, embora a autora não se refira a essa vogal diretamente. Já /e/, segundo a autora, varia livremente entre [e] e $[\varepsilon]$, sendo o fone médio-alto [e] mais recorrente; para Nicholson, essa vogal tem somente uma realização, $[\varepsilon]$. Nesta última proposta, a assimetria, novamente, está nas vogais da região média, que não possuem correspondentes na região posterior.

(7) Inventário fonético de vogais Asuriní, baseado em Pereira (2009, p. 37)

\begin{tabular}{l|c|c|c|}
\multicolumn{1}{c}{} & \multicolumn{1}{c}{ Anterior } & Central & \multicolumn{1}{c|}{ Posterior } \\
\cline { 2 - 4 } Alta & {$[\mathrm{i}]$} & {$[\mathrm{i}]$} & {$[\mathrm{u}]$} \\
\cline { 2 - 4 } Média & {$[\mathrm{e}] \sim[\varepsilon]$} & & \\
Baixa & & {$[\mathrm{a}]$} & \\
\cline { 2 - 4 } & &
\end{tabular}

Frente à diferença entre as duas propostas para o sistema vocálico do Asuriní do Xingu, a questão que este estudo tenta responder é a seguinte: quantas e quais são de fato as qualidades vocálicas da língua? A resposta pode ser obtida através de uma análise acústica.

Cada som vocálico contou com aproximadamente 15 amostras, a partir das quais os valores correspondentes aos dois principais formantes, F1 e F2, foram retirados a partir de um valor absoluto da medição da vogal; o ponto de coleta desses valores coincide geralmente com o centro da vogal, em que os formantes estão mais estáveis, conforme ilustrado com a vogal [i] na Fig. 1, abaixo. 0 objetivo desse tipo de análise é examinar acusticamente as qualidades de vogais nessa língua, para que se chegue a uma conclusão sobre seus fonemas vocálicos. 
Figura 1: Espectrograma da vogal [i] do Asuriní do Xingu

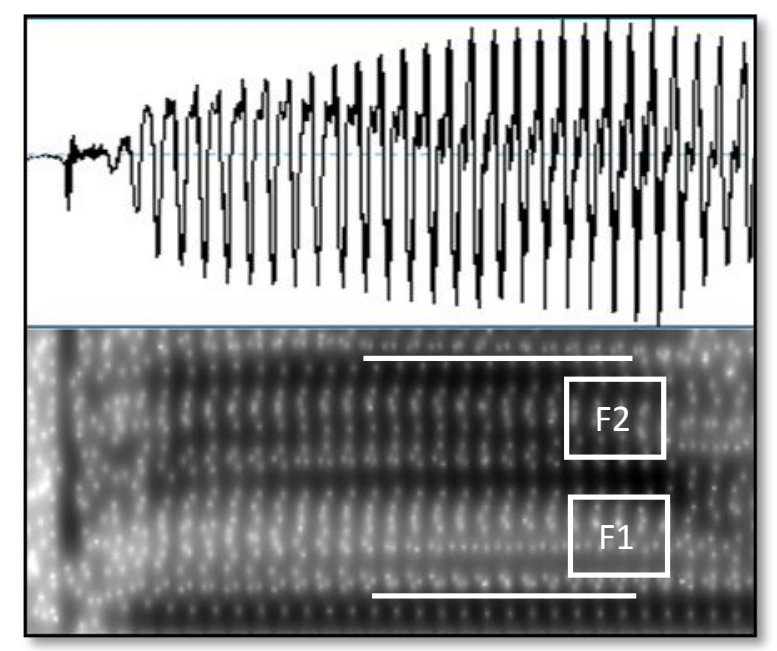

Os resultados aparecem na Fig. 2 a seguir. A dispersão acústica das vogais aponta para um sistema semelhante ao proposto por Pereira (2009), com seis qualidades: [i, e, $\varepsilon, \dot{\mathrm{i}}, \mathrm{a}, \mathrm{u}]$. A distinção entre [o] e [u] proposta por Nicholson (1982) não se confirma. Como pode ser verificado no gráfico, as duas vogais confundem-se no espaço acústico, especialmente em relação à altura. Há uma pequena diferença em relação à dimensão horizontal, sugerindo que essa vogal pode ser foneticamente realizada como [u] ou como uma vogal mais relaxada, [ひ]. Também se observa que há duas qualidades de vogal média, $[\mathrm{e}]$ e [E], como já apontado por Pereira. Das seis qualidades encontradas, a vogal mais instável do ponto de vista acústico é a vogal central [a], que varia de uma central baixa [a] até uma central média [ə]. Esta variação se justifica em função do valor das médias de F1 e F2 da vogal, conforme o Quadro 1, que mostra o desvio padrão (entre parênteses) e a média dos formantes com relação aos valores utilizados para a análise das vogais. 
Figura 2: Gráfico da dispersão acústica das vogais do Asuriní do Xingu

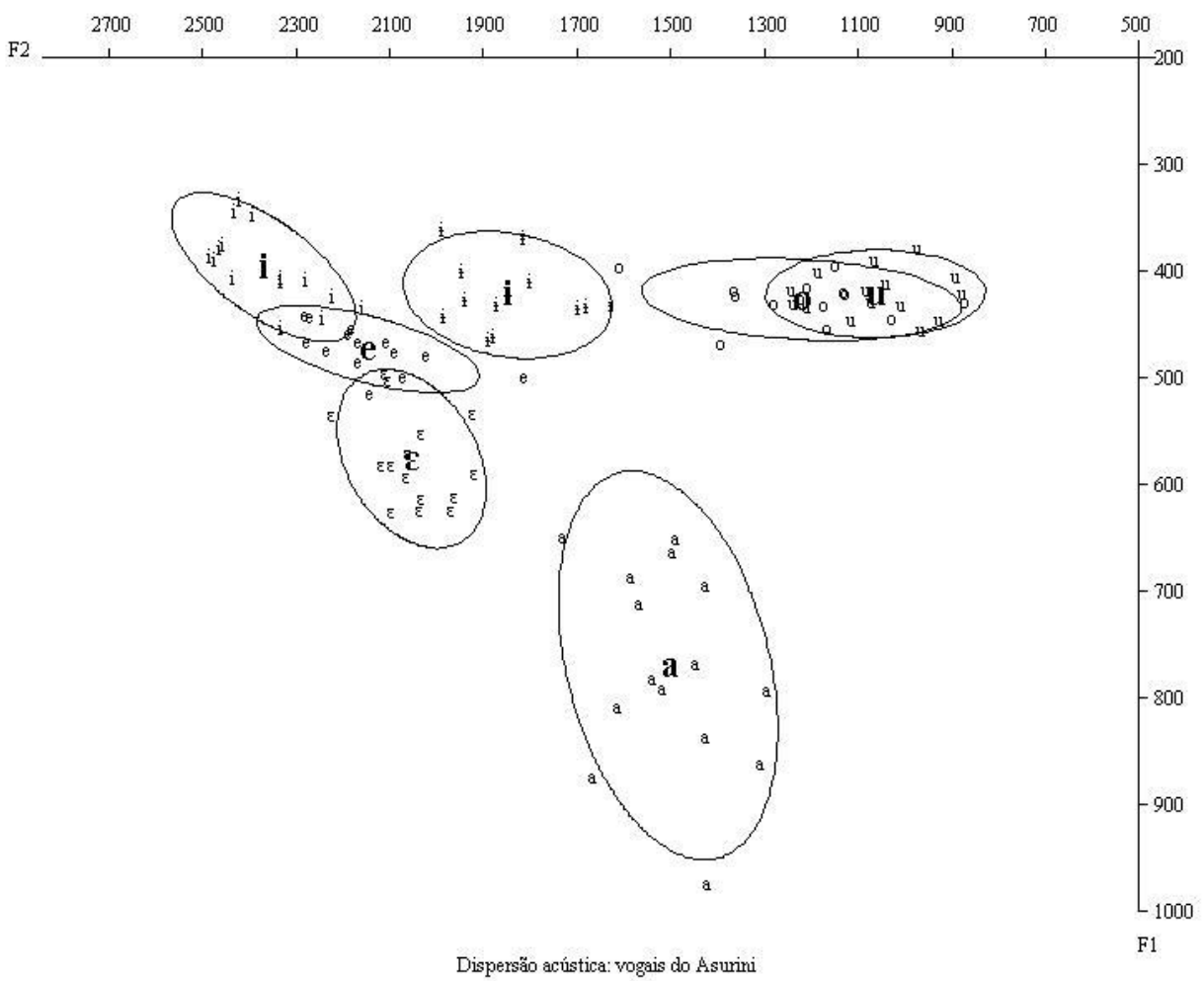

A seguir, no Quadro 1, apresentam-se as médias e desvio padrão (entre parênteses) das vogais analisadas.

Quadro 1: Médias e desvio padrão dos formantes (em Hertz)

\begin{tabular}{|c|r|r|}
\hline & F1 & F2 \\
\hline$[\mathrm{i}]$ & 390 & 2454 \\
& $(31,3)$ & $(102,5)$ \\
\hline$[\mathrm{e}]$ & 469 & 2085 \\
& $(29,4)$ & $(119,7)$ \\
\hline$[\varepsilon]$ & 558 & 1978 \\
& $(33,6)$ & $(128,8)$ \\
\hline$[\mathrm{i}]$ & 409 & 1860 \\
& $(21,0)$ & $(177,1)$ \\
\hline$[ə]$ & 461 & 1787 \\
& $(26,9)$ & $(128,4)$ \\
\hline$[\mathrm{a}]$ & 744 & 1596 \\
& $(73,2)$ & $(97,5)$ \\
\hline$[\mathrm{u}]$ & 414 & 1153 \\
& $(15,7)$ & $(157,5)$ \\
\hline \multicolumn{2}{|c|}{ Fonte: BRIT0 $(2013)$}
\end{tabular}


O estudo acústico revela, portanto, que a língua Asuriní do Xingu conta com um quadro contendo oito qualidades de vogais, são elas: três anteriores, [i, e, ع], três centrais, $[\dot{\mathrm{t}}$, ə, $\mathrm{a}]$ e duas posteriores, $[\mathrm{u}, \mathrm{v}]$. Do ponto de vista fonológico, considerando a análise de Pereira (2009), o inventário fonético-fonológico da língua seria como mostrado em (8).

Inventário fonético-fonológico das vogais do Asuriní do Xingu

\begin{tabular}{|c|c|c|c|}
\hline & Anterior & Central & Posterior \\
\hline \multirow[t]{2}{*}{ Alta } & /i/ & /ít & /u/ \\
\hline & [i] & {$[\dot{\mathrm{t}}]$} & {$[\mathrm{u}] \sim[\mathrm{v}]$} \\
\hline Média & $\begin{array}{c}/ \mathrm{e} / \\
{[\mathrm{e}] \sim[\varepsilon]}\end{array}$ & & \\
\hline Baixa & & $\begin{array}{c}\mathrm{a} / \\
{[\mathrm{a}] \sim[\partial]}\end{array}$ & \\
\hline
\end{tabular}

Se fonemicamente há uma lacuna na região média, uma vez que a vogal não possui uma correspondente posterior, foneticamente isso parece ser compensado pela dispersão de /a/, através do alofone [ə].

Os dados examinados também sugerem que a alofonia vocálica, especialmente no caso da vogal baixa /a/, pode ter alguma relação com o acento, sendo [ə] restrita a uma sílaba não acentuada, em final de palavra. No entanto, não temos ainda evidências suficientes para assumir que a variação entre [a] e [ə] é de fato condicionada pelo acento. No caso de $[\mathrm{e}]$ e $[\varepsilon]$, e $[\mathrm{u}]$ e $[\mho]$, parece realmente ser um caso de variação livre.

Em suma, o sistema vocálico do Asuriní obedece ao princípio de dispersão em que as vogais ocupam primeiramente as extremidades, formando um sistema triangular /i, u, a/, para depois ocupar os pontos mediais.

\section{Wayampí}

Assim como o Asuriní, a língua Wayampí conta com alguns estudos anteriores. A principal referência utilizada em nossa pesquisa é a dissertação "O desenvolvimento histórico da língua Wayampí" (1984), de Cheryl Joyce S. Jense. Trata-se de um trabalho 
de grande relevância no contexto linguístico da fonologia da língua, uma vez que descreve aspectos fonológicos e morfológicos da mesma, determinando as mudanças que ocorreram no Wayampí com base em reconstruções fonológicas e morfológicas do Proto-Tupí-Guaraní. Tem-se ainda o estudo de Allen Jensen (1979-2008) “Comparação Preliminar das línguas Emerillon e Oiampi no seu desenvolvimento do Proto-TupíGuaraní", que apresenta uma breve comparação entre estas duas línguas pertencentes à mesma família (Tupí-Guaraní) e subgrupo (ramo VIII) e que são originárias do norte do Rio Amazonas.

Jensen (1984) apresenta o inventário fonêmico mostrado em (9) para as vogais do Wayampí. A língua parece ter um sistema vocálico bastante simétrico que inclui, além do triângulo /i, u, a/, duas vogais na região média, sendo uma anterior e outra posterior.

(9) Inventário fonêmico das vogais Wayampí, baseado em Jensen (1984)

Anterior Central Posterior

\begin{tabular}{l|l|l|l|} 
Alta & /i/ & $/ \mathrm{i} /$ & $/ \mathrm{u} /$ \\
\cline { 2 - 4 } Média & /e/ & & $/ \mathrm{o} /$ \\
\cline { 2 - 4 } Baixa & & $/ \mathrm{a} /$ & \\
\cline { 2 - 4 } & &
\end{tabular}

Nenhum detalhe fonético referente às realizações das vogais é fornecido no estudo de Jensen. Por isso, vamos assumir que, para a autora, não há variantes alofônicas significativas na língua.

No entanto, há uma segunda proposta para a fonologia do Wayampí. Recentemente Copin (2012) apresentou um estudo buscando fornecer uma descrição sincrônica gramatical da língua. 0 autor sugere um quadro fonêmico das vogais que difere da proposta de Jensen em um aspecto importante: a ausência da vogal central alta não-arrendondada /ł/, substituída pela posterior alta não-arrendondada /u/:

(10) Inventário fonêmico das vogais Wayampí, baseado em Copin (2012, p. 412)

\begin{tabular}{l|c|c|c|}
\multicolumn{1}{c}{} & Anterior & Central & \multicolumn{1}{c}{ Posterior } \\
Alta & $/ \mathrm{i} /$ & & $/ \mathrm{u} / / \mathrm{u} /$ \\
\cline { 2 - 4 } Média & $/ \mathrm{e} /$ & & $/ \mathrm{o} /$ \\
\cline { 2 - 4 } Baixa & & $/ \mathrm{a} /$ & \\
\cline { 2 - 4 } & &
\end{tabular}


Copin fornece alguns detalhes das realizações fonéticas das vogais. De acordo com o autor, as vogais altas /i, $\mathrm{u}, \mathrm{u}$ / e a central baixa /a/ possuem uma única realização cada, $[\mathrm{i}, \mathrm{u}, \mathrm{u}]$ e [a], respectivamente; já as vogais médias /e, o/ possuem dois alofones cada: as médias altas, [e, o], em sílabas abertas, e como médias baixas, [ $\varepsilon, 0]$, em sílabas fechadas. Do ponto de vista fonético, conclui-se que o Wayampí tem oito qualidades orais de vogais:

(11) Inventário fonético das vogais Wayampí, baseado em Copin (2012)

\begin{tabular}{l|c|c|c|}
\multicolumn{1}{c}{ Anterior } & Central & \multicolumn{1}{c}{ Posterior } \\
\cline { 2 - 4 } Alta & {$[\mathrm{i}]$} & & {$[\mathrm{u}][\mathrm{u}]$} \\
\cline { 2 - 4 } Média & {$[\mathrm{e}],[\varepsilon]$} & & {$[\mathrm{o}],[\mathrm{\jmath}]$} \\
\cline { 2 - 4 } Baixa & & {$[\mathrm{a}]$} & \\
\cline { 2 - 4 } & &
\end{tabular}

$\mathrm{Na}$ investigação acústica foram observadas oito qualidades de vogais: três na região alta, [i], [i] e [u]; quatro na região média, [e], [o], [ع] e [э]; e uma vogal baixa [a]. Não se constatou a presença da vogal posterior não-arredondada [u] proposta por Copin, mas sim da central alta [i]], como defendido por Jensen (1984). Isso pode ser verificado na Fig. 3 a seguir. Em contraste, há de fato duas vogais médias, uma aberta e outra fechada, tanto na região anterior quanto na posterior, como argumenta Copin. As vogais mais estáveis em relação à dispersão no espaço acústico, isto é, aquelas que apresentam certa regularidade com relação às suas frequências, são as vogais [i], [i], [u], [a] e [0]; as médias [e], [ع] e [o] tendem a variar bastante, especialmente na dimensão vertical (altura da língua). 
Figura 3: Gráfico da dispersão acústica das vogais do Wayampí

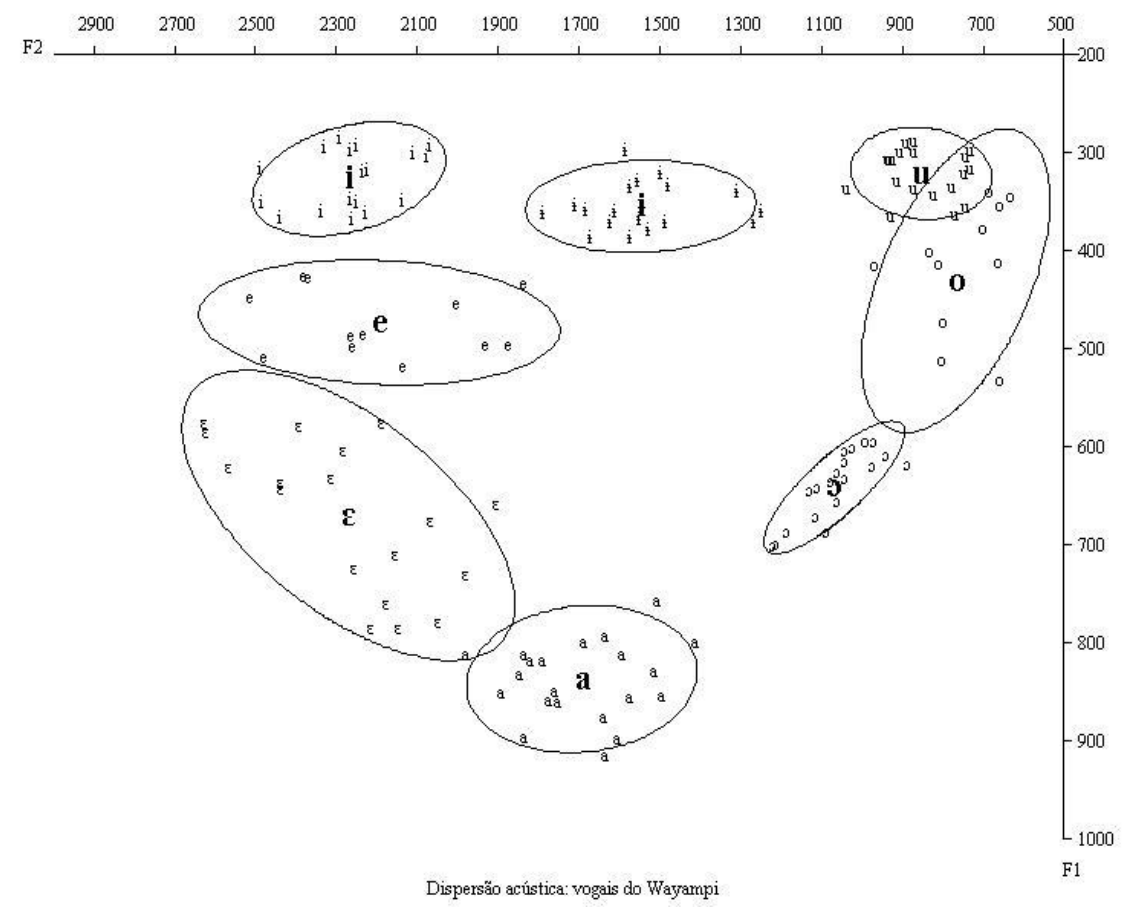

Abaixo, no Quadro 2, podem ser verificadas as médias e desvio padrão (entre parênteses) das vogais analisadas.

Quadro 2: Médias e Desvio Padrão de F1 e F2 das vogais do Wayampí

\begin{tabular}{|c|c|c|}
\hline VOGAL & F1 & F2 \\
\hline$[\mathbf{i}]$ & 328 & 2925 \\
$(28,9)$ & $(91,5)$ \\
\hline$[\mathbf{e}]$ & 475 & 2227 \\
$(31,9)$ & $(273,5)$ \\
\hline$[\mathbf{\varepsilon}]$ & 671 & 2271 \\
& $(73,9)$ & $(206,4)$ \\
\hline$[\mathbf{i}]$ & 356 & 1547 \\
& $(23,5)$ & $(143,1)$ \\
\hline$[\mathbf{u}]$ & 323 & 854 \\
& $(23,4)$ & $(87,4)$ \\
\hline$[\mathbf{o}]$ & 432 & 769 \\
& $(77,2)$ & $(116,5)$ \\
\hline$[\mathbf{0}]$ & 643 & 1070 \\
& $(34,0)$ & $(87,5)$ \\
\hline$[\mathbf{a}]$ & 839 & 1699 \\
& $(38,1)$ & $(147,1)$ \\
\hline
\end{tabular}

Fonte: Baraúna (2013)

Pode-se concluir que os estudos anteriores, tanto o de Jensen (1984) quanto o de Copin (2012), complementam-se. Jensen apresenta as vogais fonêmicas como sendo /i/, 
/e/, / i /, /a/, /u/ e /o/, e estas foram confirmadas na investigação acústica. Por outro lado, Copin apresenta os alofones abertos $[\varepsilon$, o] e fechados [e, o] das vogais médias, também constatadas. Portanto, o quadro fonético-fonológico das vogais do Wayampí, que tem por base a análise acústica, é o seguinte:

Inventário fonético-fonológico das vogais do Wayampí

Anterior Central Posterior

\begin{tabular}{l|c|c|c|}
\cline { 2 - 3 } Alta & $\begin{array}{c}/ \mathrm{i} / \\
{[\mathrm{i}]}\end{array}$ & $\begin{array}{c}/ \mathrm{i} / \\
{[\mathrm{i}]}\end{array}$ & $\begin{array}{c}/ \mathrm{u} / \\
{[\mathrm{u}]}\end{array}$ \\
\cline { 2 - 4 } Média & $/ \mathrm{e} /$ & & $/ \mathrm{o} /$ \\
& {$[\mathrm{e}],[\varepsilon]$} & & {$[\mathrm{o}],[\mathrm{J}]$} \\
\cline { 2 - 4 } Baixa & & $/ \mathrm{a} /$ & \\
& & & \\
\cline { 2 - 4 } & & &
\end{tabular}

A seguir podemos constatar as oito qualidades acústicas das vogais com base na aproximação de F1 e F2, desde a vogal alta anterior não arredondada [i] até vogal alta posterior arredonda [u]. Cabe ressaltar que estas vogais encontram-se na posição tônica das palavras

Figura 4: Espectrogramas ilustrativos dos fones vocálicos do Wayampí

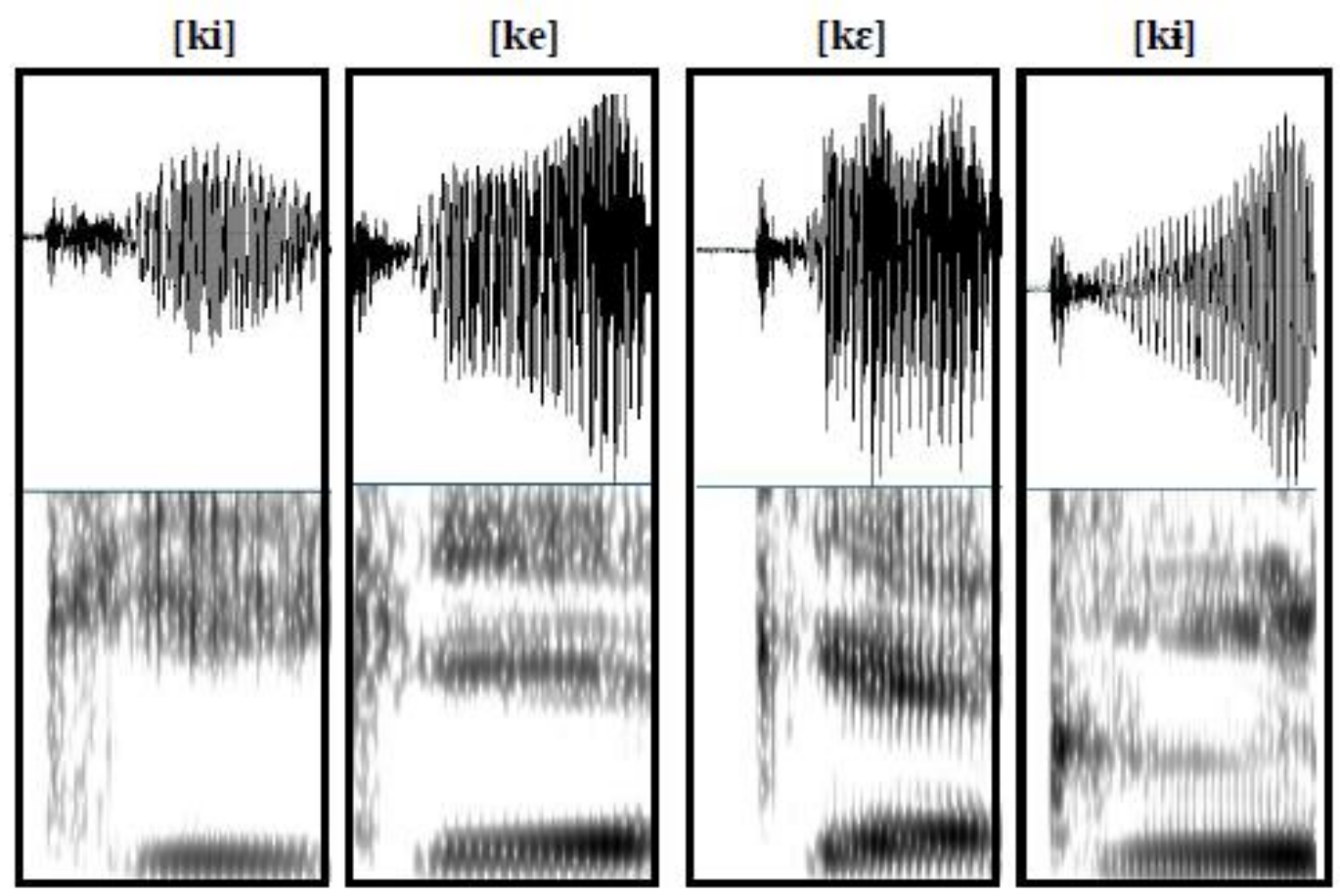


[ka]

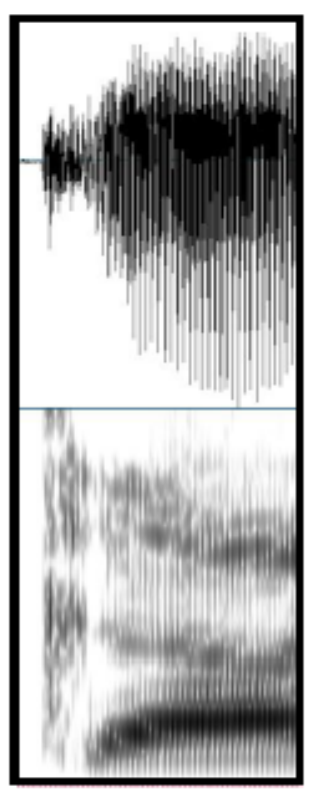

[ko]

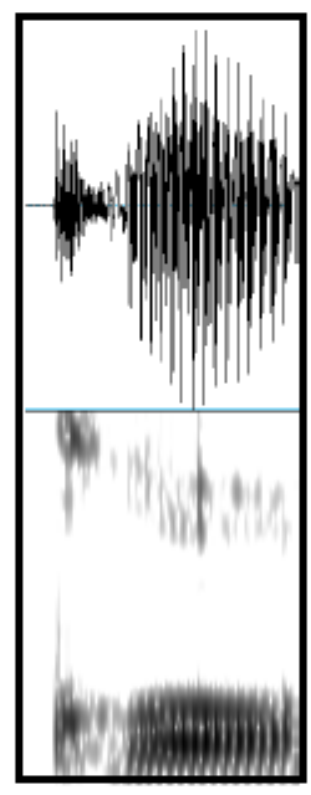

[ko]

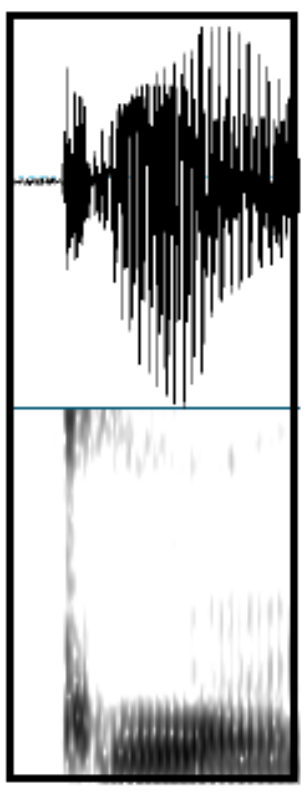

[ku]

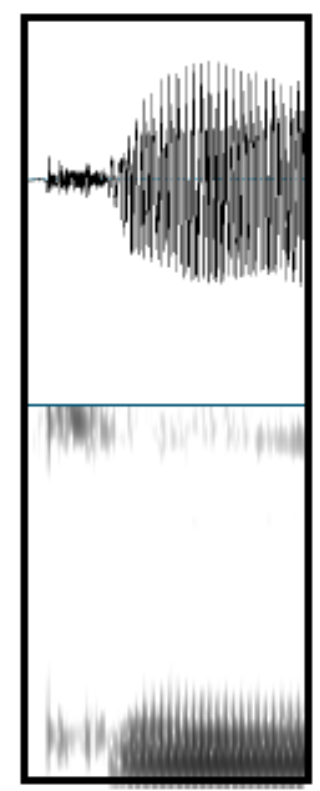

\section{Mundurukú}

Nas seções anteriores, vimos que as duas línguas examinadas estão de acordo com o princípio da dispersão vocálica, já que ambas têm o sistema triangular e são relativamente simétricas. Nesta seção iremos descrever um caso diferente, o da língua Mundurukú.

O sistema vocálico do Mundurukú é tipologicamente incomum, devido à lacuna na região posterior, em que nota-se a ausência da vogal posterior alta /u/; nessa região encontramos somente a vogal médio-alta posterior /o/. 0 sistema também não é totalmente equilibrado na região média, já que a vogal médio-alta anterior /e/, foneticamente $[\varepsilon]^{5}$, tem como correspondente as vogais [o] [u] (PICANÇO, 2005).

\footnotetext{
${ }^{5} \mathrm{~A}$ variante alofônica médio-alta de /e/, [e], ocorre somente se /e/ é seguida pelo glide /j/; nos demais ambientes é sempre realizada como a vogal médio-baixa $[\varepsilon]$.
} 
(13) Inventário fonético-fonêmico das vogais Mundurukú (PICANÇO, 2005)

\begin{tabular}{|c|c|c|c|}
\hline & Anterior & Central & Posterior \\
\hline Alta & $\begin{array}{r}\text { /i/ } \\
{[\mathrm{i}]}\end{array}$ & & \\
\hline Média & $\begin{array}{c}\mathrm{e} / \\
{[\varepsilon],[\mathrm{e}]}\end{array}$ & $\begin{array}{l}/ \partial / \\
{[\partial]}\end{array}$ & $\begin{array}{c}\mathrm{o} / \\
{[\mathrm{o}] \sim[\mathrm{u}]}\end{array}$ \\
\hline Baixa & & $\begin{array}{l}\text { /a/ } \\
{[\mathrm{a}]}\end{array}$ & \\
\hline
\end{tabular}

O Mundurukú parece contradizer o princípio da dispersão vocálica (LILJENCRANTS \& LINDBLOM, 1972), pois seu sistema tem uma grande lacuna na região posterior alta, além de uma distribuição desigual das vogais médias; ou seja, a língua não possui o esperado sistema triangular e é assimétrica em relação à altura vocálica. No entanto, evidências internas sugerem que, ainda assim, a língua segue o modelo de Liljencrants \& Lindblom (1972) e também de Lindblom (1986).

Segundo Sandra Disner (apud MADDIESON, 1984), sistemas defectivos tendem a compensar suas lacunas através de outras vogais; ou seja, as vogais disponíveis são distribuídas de modo a tornar o sistema parecido com um de distribuição simétrica. Disner (p. 144) relata três tipos principais de vogais complementares: (i) uma vogal central, (ii) uma vogal anterior arredondada ou posterior não-arredondada, ou (iii) uma vogal periférica similar à vogal ausente, mas sem uma correspondente de mesma altura ou oposta em arredondamento.

Picanço (2005) também fez uso de análise acústica para determinar as qualidades e áreas exatas de dispersão das vogais do Mundurukú. 0 gráfico abaixo mostra os resultados. 
Figura 5: Dispersão acústica das vogais do Mundurukú (PICANÇO, 2005, p. 22)

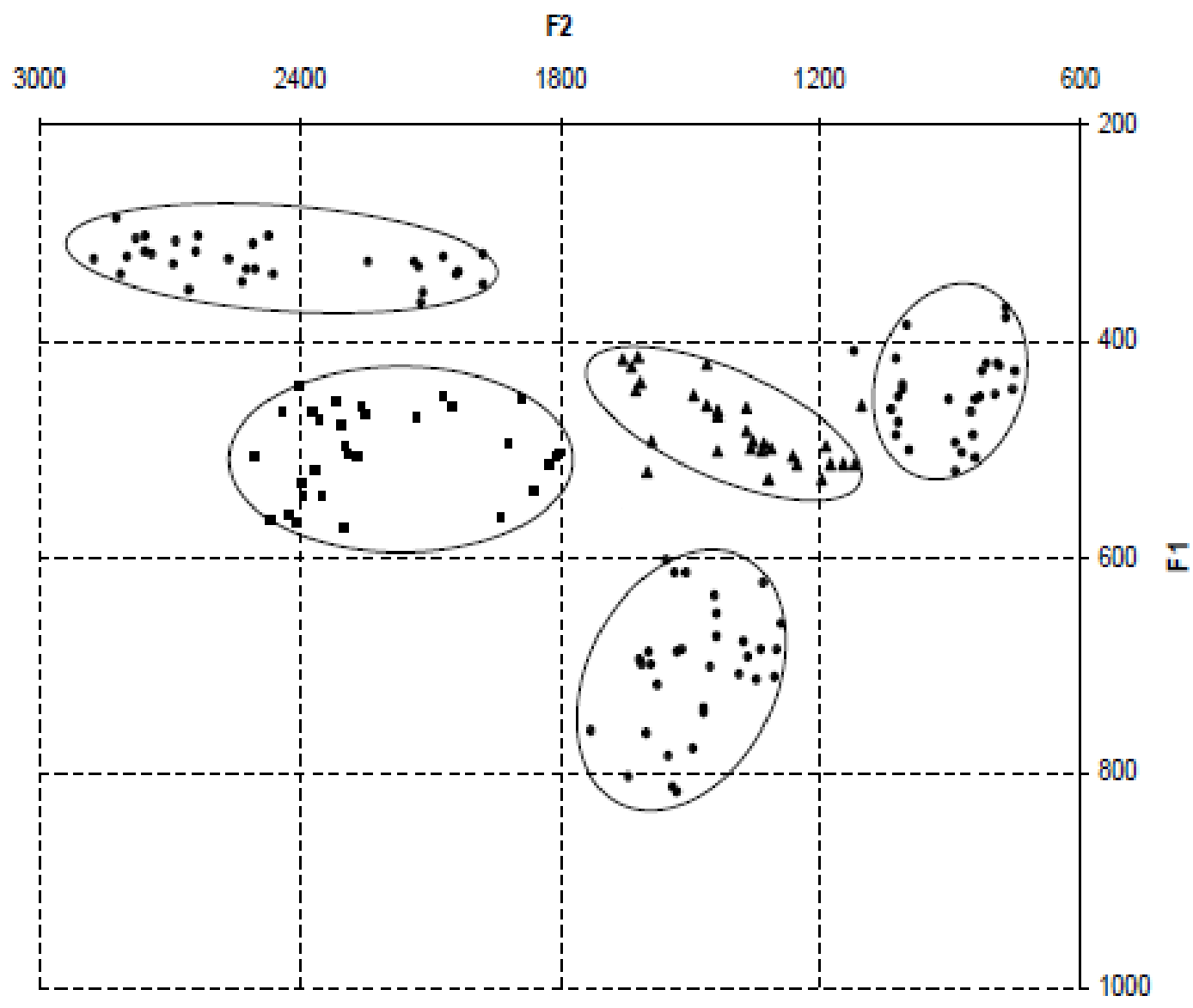

De acordo com a investigação acústica oferecida por Picanço (2005), há alguns desvios na distribuição das vogais do Mundurukú dentro do espaço acústico, mas não a ponto de excluir a possibilidade de que as lacunas podem ser compensadas por outras vogais do sistema. Ao compararmos a vogal anterior [ $\varepsilon$ ] à central [ə] e a [o], notamos

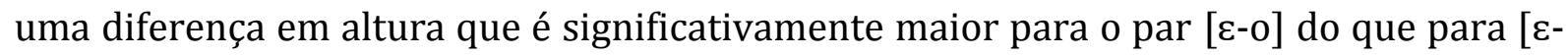
ə], o que torna plausível sugerir que [ə] é a vogal que funciona como uma correspondente de $[\varepsilon]$, em vez de [o]. Picanço (2005) também demonstra que, embora haja uma diferença significativa em altura entre [i] e [o], o fonema /o/ tem como variante livre o fone [u]. Com isso, pode-se dizer que /o/ está para /i/, assim como /ə/ está para /e/. Visto dessa maneira, o sistema vocálico do Mundurukú distribui suas vogais igualmente, mesmo que para tal recorra à compensação. 


\section{Conclusão}

Este estudo procurou mostrar a importância de uma análise fonética, especificamente acústica, na discussão de fatos fonológicos. Esse tipo de análise contribui substancialmente para uma descrição mais precisa das realizações fonéticas de segmentos que, nos casos discutidos aqui, referia-se à definição das qualidades fonéticas e sua distribuição no espaço acústico de vogais. As três línguas examinadas, Asuriní do Xingu, Wayampí e Mundurukú, todas do tronco Tupí, serviram como exemplos para a discussão. 0 Asuriní, com seu sistema relativamente bem distribuído, permanecia indefinido em relação a suas qualidades vocálicas, um problema semelhante ao encontrado no Wayampí; essa língua possui um sistema vocálico simetricamente arranjado, mas também havia dúvidas quanto às suas vogais. A análise acústica contribuiu para esclarecer as diferenças. O Mundurukú, por outro lado, foi usado como um bom exemplo de uma língua tipologicamente incomum, já que não possui em seu sistema vocálico o triângulo /i, u, a/. No entanto, a análise acústica demonstrou que parece haver uma compensação por parte das vogais atuais, aproximando a língua da simetria que é esperada na distribuição de vogais.

\section{Referências}

BARAÚNA, Fabíola Azevedo. Aspectos fonéticos e fonológicos da língua Wayampi. 2013. 47 f. Trabalho de Conclusão de Curso. Universidade Federal do Pará. Belém, 2013.

BRITO, Alessandra Janaú. Uma abordagem acústica da língua Asurini do Xingu. 2013. 45 f. Trabalho de Conclusão de Curso. Universidade Federal do Pará. Belém, 2013.

COPIN, François. Grammaire Wayampi (famille Tupi-Guaraní). 2012. 463 f. Tese (Doutorado em Linguística) - Département de Sciences du Langage, Université Paris 7 / Denis Diderot, França, 2012.

CROTHERS, John. Typlogy and universals of vowel systems. In: GREENBERG, Joseph Harold. (Org.), Universlas of Human Language, Vol. I: Theory and Methodology. Stanford: Stanford University Press. 1978, p. 93-152.

Instituto Socioambiental. Povos Indígenas no Brasil. Disponível em: <http://ti.socioambiental.org/\#!/terras-indigenas/3733>. Acesso em: 07 abr. 2014. 
JENSEN, Cheryl S. O desenvolvimento histórico da língua Wayampi. 1984. $187 \mathrm{f}$. Dissertação (Mestrado) - Instituto de Estudos da Linguagem, Universidade Estadual de Campinas, Campinas, 1984.

LADEFOGED, Peter. Preliminaries to Linguistic Phonetics. Chicago \& London: The University of Chicago Press, 1971.

LILJENCRANTS, Johan; LINDBLOM, Bjorn. Numerical simulation of vowel quality systems: the role of perceptual contrast. Language, n. 48, p. 839-862, 1972.

LINDBLOM, Björn. Phonetic universals in vowel systems. In: OHALA, J. J.; JAEGER, J. (Ed.). Experimental Phonology. Orlando: Academic Press, 1986, p.13-44.

MADDIESON, Ian. Patterns of Sounds. Cambridge: Cambridge University Press, 1984.

MADDIESON, Ian; PRECODA, Kristin. Updating UPSID. UCLA Working Papers in Phonetics, 74, p.104-111, 1989.

MELlO, Augusto. Estudo Histórico da Família Linguística Tupí-Guaraní: Aspectos Fonológicos e Lexicais. 2000. 285 f. Tese (Doutorado em Linguística) - Programa de PósGraduação, Universidade de Santa Catarina, Florianópolis, 2000.

NICHOLSON, Velda. Breve Estudo da Língua Asurini do Xingu. Brasília: Publicações do SIL, Ensaios Linguísticos, n. 5, 1982.

NICHOLSON, Velda. Aspectos da língua Asurini. Brasília: Publicações do SIL, 1978.

PEREIRA, Antonia Alves. Estudo morfossintático do Asurini do Xingu. 2009. 348 f. Tese (Doutorado em Linguística) - Programa de Pós-Graduação em Linguística, Universidade Estadual de Campinas, Campinas, 2009.

PICANÇO. Gessiane. Mundurukú: Phonetics, Phonology, Synchrony, Diachrony. 2005. 424 f. Tese (Doutorado em Linguística) - Departamento de Linguística da University of British Columbia, Canadá, 2005.

RODRIGUES, Aryon Dall'Igna. Línguas brasileiras: para o conhecimento das línguas indígenas. São Paulo: Loyola. 1986.

RODRIGUES, Aryon Dall'Igna; CABRAL, Ana Suelly Arruda Câmara (Org.). Línguas Indígenas Brasileiras: Fonologia, Gramática e História. Atas do I Encontro Internacional do Grupo de Trabalho sobre Línguas Indígenas da ANPOLL. Belém: EDUFPA, 2002.

SILVA, Renata Oliveira. Características acústicas e articulatórias das vogais postônicas na variedade do Português Brasiliense. 2012. 151 f. Dissertação (Mestrado) - Departamento de Linguística, Línguas Clássicas e Português. Universidade de Brasília, Brasília, 2012. 
TROUBETZKOY, Nikolay Sergeyevich. Grundzüge der Phonologie. 1939. Trad. inglesa por Christiane Baltaxe, Principles of Phonology. Berkeley/Los Angeles: University of California Press, 1969. 
ANEXO 1

Lista de palavras utilizadas para formar o quadro de dispersão acústica da língua Asuriní do Xingu

\begin{tabular}{|c|c|c|c|}
\hline Vogal & Transcrição fonêmica & Transcrição fonética & Glosa \\
\hline [i] & $\begin{array}{l}\text { /epipik/ } \\
\text { /i/ } \\
\text { /ipeni/ } \\
\text { /ḑerurip/ } \\
\text { /mũnußi/ } \\
\text { /parati/ } \\
\text { /akait/ } \\
\text { /amudik/ } \\
\text { /upirik/ } \\
\text { /dgitik/ } \\
\text { /pimij/ } \\
\text { /dgeti/ } \\
\text { /akait/ } \\
\text { /atimi/ } \\
\text { /parati/ }\end{array}$ & 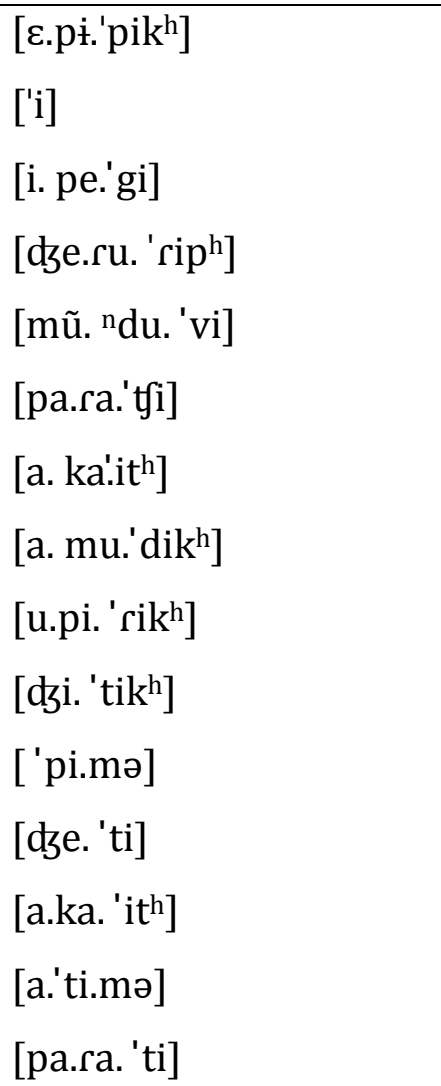 & $\begin{array}{l}\text { 'afogar' } \\
\text { 'água' } \\
\text { 'águia' } \\
\text { 'alegre/feliz' } \\
\text { 'amendoim' } \\
\text { 'anzol' } \\
\text { 'arranhar' } \\
\text { 'arrebentar' } \\
\text { 'atirar' } \\
\text { 'batata' } \\
\text { 'beija-flor' } \\
\text { 'bexiga' } \\
\text { 'coçar' } \\
\text { 'colher' } \\
\text { 'correnteza' }\end{array}$ \\
\hline [e] & $\begin{array}{l}\text { /tapek }{ }^{w} a ß \dot{t} / \\
\text { /ipeni/ } \\
\text { /yapepa/ } \\
\text { /dzeraẽ/ } \\
\text { /dzepepu?iri/ } \\
\text { /dzekawa/ } \\
\text { /dzeraweri/ } \\
\text { /dzepimã/ } \\
\text { /aperemu/ } \\
\text { /dzeti/ } \\
\text { /dzedzuru/ }\end{array}$ & $\begin{array}{l}\text { [ta.pe.'kwa.ßə] } \\
\text { [i.pe.'gi] } \\
\text { ['ga.pe.'pa] } \\
\text { [dze.ra.'ẽ] } \\
\text { [dze.pe.фu. ' Pi.rə] } \\
\text { [dze.'ka.wa] } \\
\text { [dze. ra. 'we.rə] } \\
\text { [dze.'pi.mã] } \\
\text { [a.pe.re.'bu] } \\
\text { [dze.'ti] } \\
\text { [dze.dzu.'ru] }\end{array}$ & $\begin{array}{l}\text { 'abano' } \\
\text { 'águia' } \\
\text { 'asa' } \\
\text { 'assoviar' } \\
\text { 'axilas' } \\
\text { 'gordura' } \\
\text { 'barriga' } \\
\text { 'beliscar' } \\
\text { 'besouro' } \\
\text { 'bexiga' } \\
\text { 'boca' }\end{array}$ \\
\hline
\end{tabular}




\begin{tabular}{|c|c|c|c|}
\hline & $\begin{array}{l}\text { /dgeratipi/ } \\
\text { /dzedzißa/ } \\
\text { /dze?ußì } \\
\text { /udzematĩ/ }\end{array}$ & $\begin{array}{l}\text { [dze.ra.ti.'pi] } \\
\text { [dze.'dzi.ßa] } \\
\text { [dze. ''?u.ßə] } \\
\text { [u.dze.ma.'tĩ] }\end{array}$ & $\begin{array}{l}\text { 'bochecha' } \\
\text { 'braço' } \\
\text { 'coxa' } \\
\text { 'crescer' }\end{array}$ \\
\hline$[\varepsilon]$ & 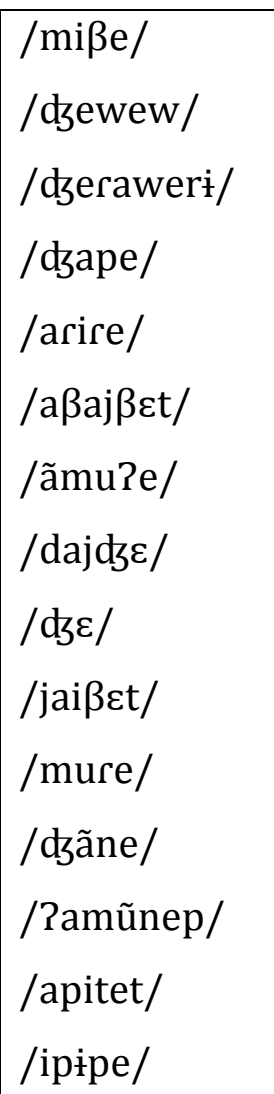 & 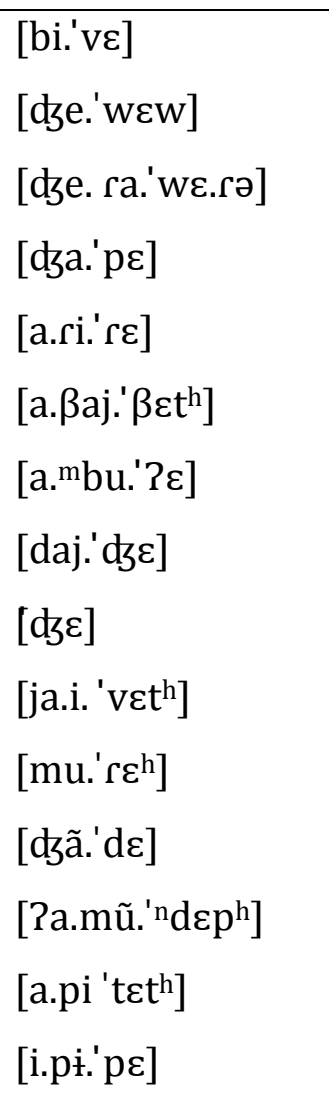 & $\begin{array}{l}\text { 'antigamente' } \\
\text { 'arrotar' } \\
\text { 'barriga' } \\
\text { 'costas' } \\
\text { 'depois' } \\
\text { 'cabelo enrolado' } \\
\text { 'ensinar' } \\
\text { 'esperar' } \\
\text { 'eu' } \\
\text { 'feio' } \\
\text { 'flauta' } \\
\text { 'nós duas' } \\
\text { 'guardar' } \\
\text { 'beijar' } \\
\text { 'dentro' }\end{array}$ \\
\hline$[\mathbf{i}]$ & 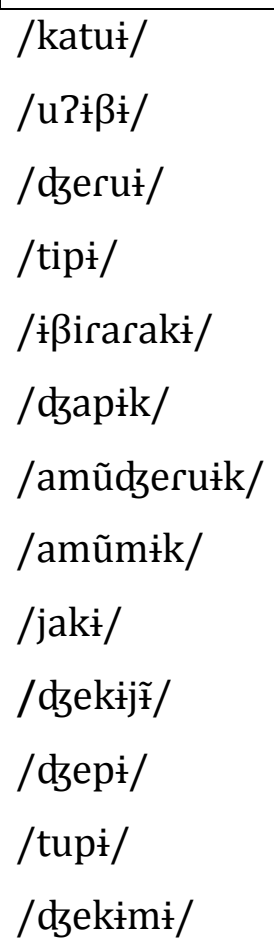 & 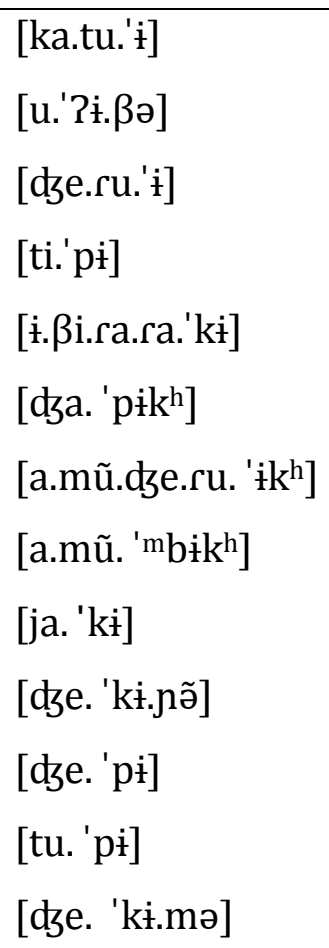 & $\begin{array}{l}\text { 'bonito' } \\
\text { 'flecha' } \\
\text { 'frio' } \\
\text { 'fundo (rio)' } \\
\text { 'galho da árvore' } \\
\text { 'conseguir' } \\
\text { 'contar'(números) } \\
\text { 'costurar' } \\
\text { 'lenha' } \\
\text { 'osso' } \\
\text { 'pé' } \\
\text { 'relâmpago' } \\
\text { 'seio' }\end{array}$ \\
\hline
\end{tabular}




\begin{tabular}{|c|c|c|c|}
\hline & 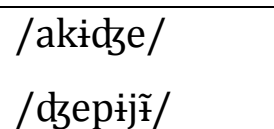 & 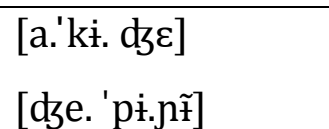 & $\begin{array}{l}\text { 'ter medo' } \\
\text { 'tornozelo' }\end{array}$ \\
\hline [ә] & 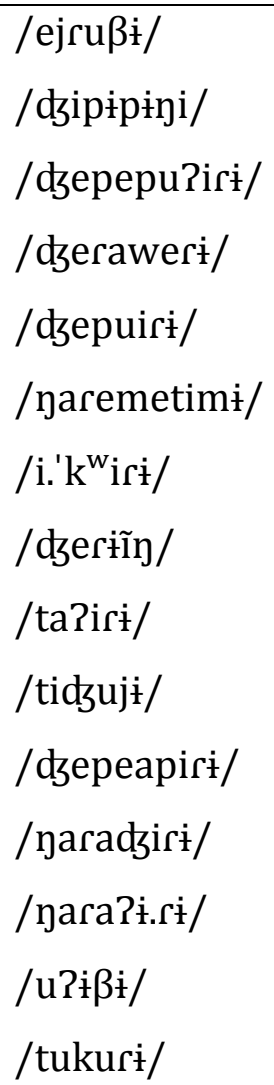 & 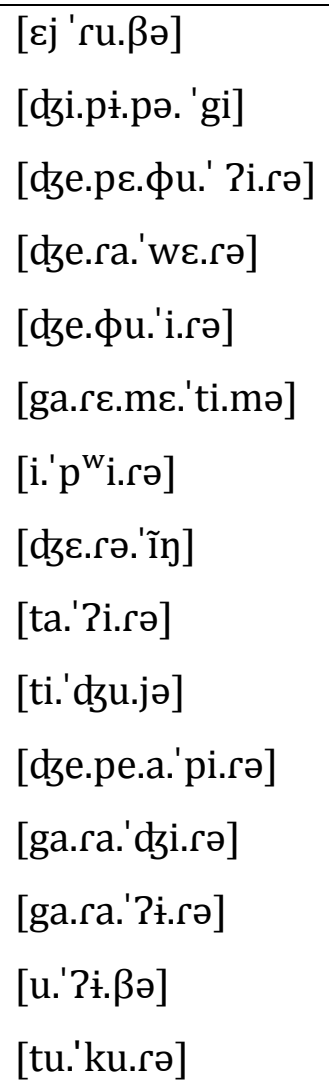 & $\begin{array}{l}\text { 'abelha' } \\
\text { 'arroz' } \\
\text { 'axilas' } \\
\text { 'barriga' } \\
\text { 'colar' } \\
\text { 'colméia' } \\
\text { 'algo cozido' } \\
\text { 'dente' } \\
\text { 'esperma' } \\
\text { 'espuma' } \\
\text { 'estômago' } \\
\text { 'filha do homem' } \\
\text { 'filho do homem' } \\
\text { 'flecha' } \\
\text { 'gafanhoto' }\end{array}$ \\
\hline [a] & $\begin{array}{l}\text { /ai/ } \\
\text { /irap/ } \\
\text { /ata/ } \\
\text { /emutaj/ } \\
\text { /ißira/ } \\
\text { /gapepa/ } \\
\text { /dzanat/ } \\
\text { /ḑekawa/ } \\
\text { /amutaßa/ } \\
\text { /urua/ } \\
\text { /marita/ } \\
\text { /dzãna/ } \\
\text { /jejĩ?a/ } \\
\text { /amãnak/ } \\
\text { /iapat/ }\end{array}$ & 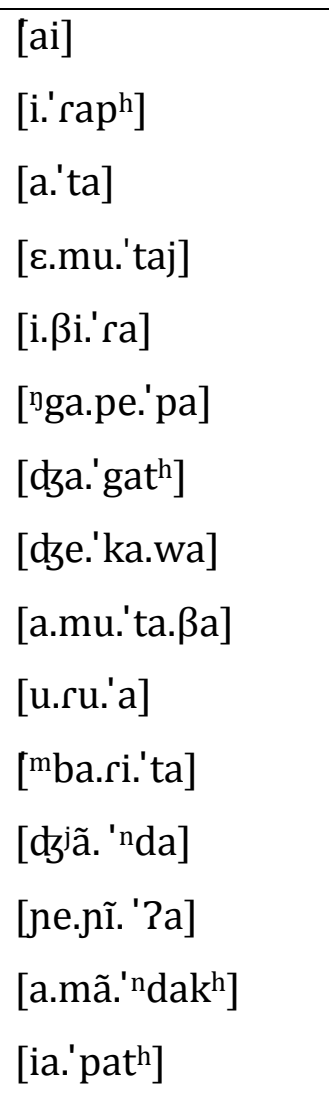 & $\begin{array}{l}\text { 'azedo' } \\
\text { 'amargo' } \\
\text { 'andar' } \\
\text { 'apimentar' } \\
\text { 'árvore' } \\
\text { 'asa' } \\
\text { 'assustar' } \\
\text { 'gordura' } \\
\text { 'barba' } \\
\text { 'caracol' } \\
\text { 'côco' } \\
\text { 'pena' } \\
\text { 'coração' } \\
\text { 'cortar' } \\
\text { 'coxo' }\end{array}$ \\
\hline
\end{tabular}


ANEXO 2

Lista de palavras utilizadas para formar o quadro de dispersão acústica da língua Wayampí

\begin{tabular}{|c|c|c|c|}
\hline Vogal & $\begin{array}{c}\text { Transcrição } \\
\text { fonêmica }\end{array}$ & $\begin{array}{c}\text { Transcrição } \\
\text { fonética }\end{array}$ & Glosa \\
\hline [i] & $\begin{array}{l}\text { /eopisi/ } \\
\text { /emari/ } \\
\text { /orori/ } \\
\text { /ikasi/ } \\
\text { /nikasi/ } \\
\text { /abasi/ }\end{array}$ & $\begin{array}{l}\text { [Eo.pi.'si] } \\
\text { [e.ma.'rih] } \\
\text { [э.ro.'rih] } \\
\text { [i.ka.'sih] } \\
\text { [ni.ka.'si] } \\
\text { [a.ba.'sih] [a.ßa.'sih] }\end{array}$ & $\begin{array}{l}\text { 'alcançar' } \\
\text { 'barriga' } \\
\text { 'camaleão' } \\
\text { 'forte' } \\
\text { 'fraco' } \\
\text { 'milho' }\end{array}$ \\
\hline [e] & $\begin{array}{l}\text { /ibiripe/ } \\
\text { /ikabẽte/ } \\
\text { /basej/ } \\
\text { /bĩme/ } \\
\text { /emi/ } \\
\text { /emari/ }\end{array}$ & $\begin{array}{l}\text { [i.wi..d di.'pe] } \\
\text { [i.ka.wẽ.'teh] } \\
\text { [wa.'sej] } \\
\text { [wĩ.'meh] } \\
\text { [e.'mih] } \\
\text { [e.ma.'rih] }\end{array}$ & $\begin{array}{l}\text { 'embaixo' } \\
\text { 'gordo' } \\
\text { 'açaí' } \\
\text { 'lá' } \\
\text { 'assar' } \\
\text { 'barriga' }\end{array}$ \\
\hline$[\varepsilon]$ & $\begin{array}{l}\text { /ipere/ } \\
\text { /ike/ } \\
\text { /ere/ } \\
\text { /eke/ } \\
\text { /sere/ } \\
\text { /ije/ }\end{array}$ & 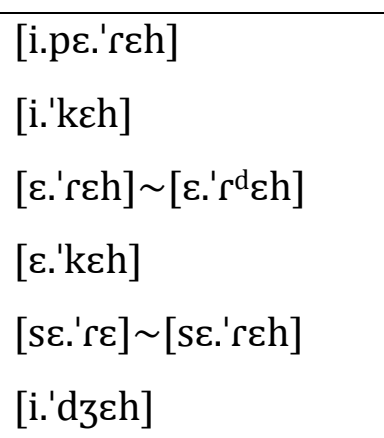 & $\begin{array}{l}\text { 'ferida' } \\
\text { 'aqui' } \\
\text { 'lamber' } \\
\text { 'dormir' } \\
\text { 'colher' } \\
\text { 'eu' }\end{array}$ \\
\hline [i] & $\begin{array}{l}\text { /ijił/ } \\
\text { /epí/ } \\
\text { /isuki/ } \\
\text { /akiki/ } \\
\text { /jiti/ } \\
\text { /isaki/ }\end{array}$ & $\begin{array}{l}\text { [i.'dzih] } \\
\text { [e.'pih] } \\
\text { [i.su.'kih] } \\
\text { [a.ki.'kih] } \\
\text { [dzi. 'tih] } \\
\text { [i.sa.'kih] }\end{array}$ & $\begin{array}{l}\text { 'barro' } \\
\text { 'buscar' } \\
\text { 'branco (cor)' } \\
\text { 'guariba(macaco)' } \\
\text { 'batata' } \\
\text { 'nascer' }\end{array}$ \\
\hline
\end{tabular}




\begin{tabular}{|c|c|c|c|}
\hline [a] & $\begin{array}{l}\text { /ika/ } \\
\text { /ipa/ } \\
\text { /era/ } \\
\text { /ibira/ } \\
\text { /apika/ } \\
\text { /eroba/ } \\
\text { /eata/ }\end{array}$ & 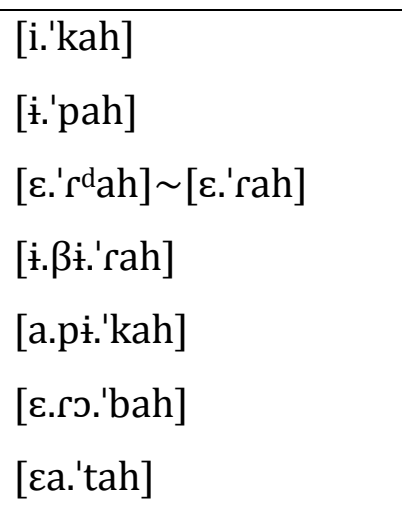 & $\begin{array}{l}\text { 'banha (gordura)' } \\
\text { 'lago' } \\
\text { 'levar' } \\
\text { 'árvore' } \\
\text { 'banco' } \\
\text { 'bochecha' } \\
\text { 'andar' }\end{array}$ \\
\hline$[\mathbf{u}]$ & $\begin{array}{l}\text { /motu/ } \\
\text { /emssusu/ } \\
\text { /taitetu/ } \\
\text { /ekatu/ } \\
\text { /ekusu/ } \\
\text { /takuru/ }\end{array}$ & 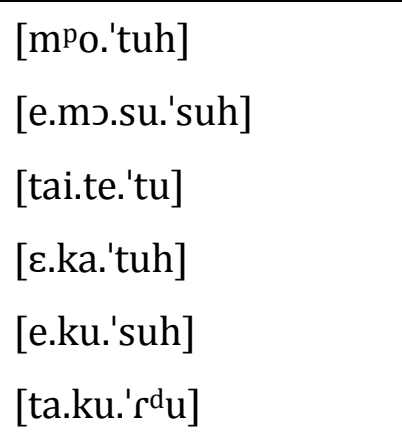 & $\begin{array}{l}\text { 'borrachudo' 'mamar' } \\
\text { 'catitu' } \\
\text { 'gostoso' } \\
\text { 'lavar' } \\
\text { 'pedra' }\end{array}$ \\
\hline [o] & $\begin{array}{l}\text { /jatebo/ } \\
\text { /nikatoj/ } \\
\text { /nopizi/ } \\
\text { /porore/ } \\
\text { /esoru/ } \\
\text { /tíroerãpa/ }\end{array}$ & 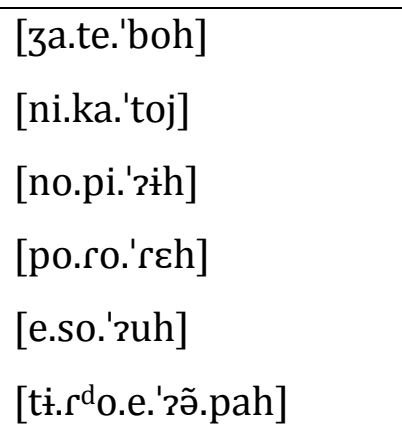 & $\begin{array}{l}\text { 'carrapato' } \\
\text { 'feio' } \\
\text { 'brincar' } \\
\text { 'enxada' } \\
\text { 'morder' } \\
\text { 'nu' }\end{array}$ \\
\hline [ग] & $\begin{array}{l}\text { /irə/ } \\
\text { /epэ/ } \\
\text { /ipoks/ } \\
\text { /epirs/ } \\
\text { /izaribs/ } \\
\text { /aribo/ }\end{array}$ & 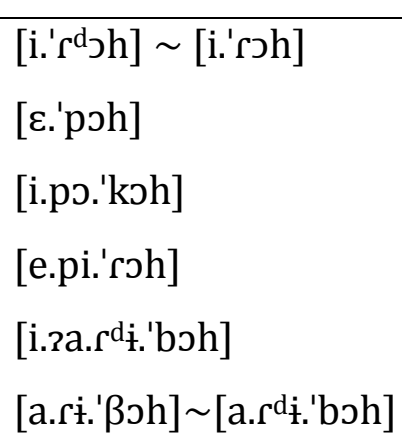 & $\begin{array}{l}\text { 'azedo' } \\
\text { 'dedo' } \\
\text { 'alto' } \\
\text { 'descascar' } \\
\text { 'em cima' } \\
\text { 'dia' }\end{array}$ \\
\hline
\end{tabular}




\section{ANEXO 3}

Lista de palavras utilizadas para formar o quadro de dispersão acústica da língua Mundurukú (tons não marcados)

\begin{tabular}{|c|c|c|c|}
\hline Vogal & $\begin{array}{c}\text { Transcrição } \\
\text { fonêmica }\end{array}$ & $\begin{array}{c}\text { Transcrição } \\
\text { fonética }\end{array}$ & Glosa \\
\hline [i] & $\begin{array}{l}\text { /ibapik/ } \\
\text { /ihi/ }\end{array}$ & $\begin{array}{l}\text { [ibapik] } \\
\text { [ihi] }\end{array}$ & $\begin{array}{l}\text { 'Seu braço está queimado' } \\
\text { 'inverno' }\end{array}$ \\
\hline [ع] & $\begin{array}{l}\text { /ibạpek/ } \\
\text { /hem/ }\end{array}$ & 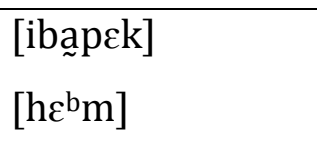 & $\begin{array}{l}\text { 'Seu braço está amarelo’ } \\
\text { 'tabaco (enfático)’ }\end{array}$ \\
\hline [ə] & $\begin{array}{l}\text { /ibapək/ } \\
\text { /dzeəhəm/ }\end{array}$ & $\begin{array}{l}\text { [ibapək] } \\
{\left[\mathrm{d} \varepsilon ə h \partial^{\mathrm{b}} \mathrm{m}\right]}\end{array}$ & $\begin{array}{l}\text { 'Está aparente' } \\
\text { 'subir' }\end{array}$ \\
\hline [a] & $\begin{array}{l}\text { /ibapak/ } \\
\text { /iaham/ }\end{array}$ & $\begin{array}{l}\text { [ibapak] } \\
{\left[\text { iahabm] }^{b} \mathrm{~m}\right.}\end{array}$ & $\begin{array}{l}\text { 'Seu braço está vermelho' } \\
\text { 'morder algo' }\end{array}$ \\
\hline [o] & $\begin{array}{l}\text { /iməpok/ } \\
\text { /oho?a/ }\end{array}$ & $\begin{array}{l}\text { [iməpok] } \\
\text { [oho?a] }\end{array}$ & $\begin{array}{l}\text { 'bater em alguém' } \\
\text { 'flauta' }\end{array}$ \\
\hline
\end{tabular}

Recebido em junho de 2014.

Aceito em novembro de 2014. 